\title{
Synovial fluid copper and related variables in rheumatoid and degenerative arthritis
}

\author{
P. R. SCUDDER, W. McMURRAY, A. G. WHITE, AND T. L. DORMANDY \\ From the Departments of Chemical Pathology and Rheumatology, Whittington Hospital, London
}

SUMMARY Copper, caeruloplasmin, transferrin, albumin, and total protein were measured in the serum and synovial fluid of 40 patients with rheumatoid arthritis and 40 patients with osteoarthrosis. A raised synovial fluid copper and caeruloplasmin have been found to be characteristic of rheumatoid effusions. The relation between copper and caeruloplasmin in synovial fluid differs from that in serum. Synovial fluid caeruloplasmin was increased disproportionately in relation to other plasma proteins present in rheumatoid effusions.

In the light of accumulating evidence pointing to an abnormal copper and caeruloplasmin metabolism in rheumatoid arthritis (RA) (Scudder et al., 1978) we decided to study copper levels and related variables in the synovial fluid of RA patients and a control group of patients with degenerative arthritis. Synovial fluid findings were also related to serum levels and the serum/synovial fluid partition of different proteins was calculated.

\section{Material}

Synovial fluid and blood were collected from 40 patients with RA (33 females, 7 males) and from a control group of 40 patients with osteoarthrosis (24 females, 16 males). The RA patients were being treated with conventional analgesic and antiinflammatory drugs (salicylates, ibuprofen, and indomethacin). None was receiving D-penicillamine or sodium aurothiomalate.

Methods

SERUM AND SYNOVIAL FLUID COPPER

Copper was measured with a Perkin Elmer model 306 atomic absorption spectrophotometer. Proteinfree extracts were prepared by dilution of the serum or synovial fluid with 1 volume of $200 \mathrm{~g} / 1$ trichloroacetic acid followed by mixing and centrifugation. The supernatants were aspirated directly into an air/acetylene flame.

Accepted for publication May 10, 1977

Correspondence to Dr T. L. Dormandy, Department of Chemical Pathology, Whittington Hospital, Archway Wing, Archway Road, London N19 3UA
TOTAL PROTEIN AND ALBUMIN

Total protein and albumin were measured by standard autoanalyser methods using the biuret and bromocresol green reactions respectively.

TRANSFERRIN AND CAERULOPLASMIN

Transferrin and caeruloplasmin were estimated by single radial immunodiffusion (Mancini et al., 1965). Commercially prepared M-Partigen immunodiffusion plates and lyophilised protein standards were obtained from Hoechst Pharmaceuticals, Hounslow, UK. Non-caeruloplasmin-bound copper was calculated as the difference between total and caeruloplasmin-bound copper. Caeruloplasmin-bound copper was calculated assuming that the copper content $\mathrm{w} / \mathrm{w}$ of caeruloplasmin is $\mathbf{0 . 3 2} \%$ (Kasper and Deutsch, 1963).

\section{Results}

Copper and caeruloplasmin were significantly increased $(P<0.01)$ in the RA group compared with the osteoarthrotic group. There was a strong positive correlation between synovial fluid copper

Table 1 Synovial fluid copper and caeruloplasmin (mean $\pm S D$ ) in patients with osteoarthrosis (control group) and with rheumatoid arthritis

\begin{tabular}{llll}
\hline & $n$ & $\begin{array}{l}\text { Copper } \\
(\mu \mathrm{mol} / \mathrm{l})\end{array}$ & $\begin{array}{l}\text { Caeruloplasmin } \\
(\mathrm{mg} / \mathrm{l})\end{array}$ \\
\hline $\begin{array}{l}\text { Control } \\
\text { group }\end{array}$ & 40 & $7 \cdot 7 \pm 3 \cdot 0$ & $141 \pm 62$ \\
$\begin{array}{l}\text { Rheumatoid } \\
\text { group }\end{array}$ & 40 & $13 \cdot 8 \pm 4 \cdot 8$ & $310 \pm 16$ \\
\hline
\end{tabular}

Conversion: SI to traditional units-

Copper: $1 \mu \mathrm{mol} / 1 \approx 6 \cdot 37 \mu \mathrm{g} / 100 \mathrm{ml}$. 
Table 2 Partition of total protein, albumin, transferrin, and caeruloplasmin (mean $\pm S D)$ between serum $(S)$ and synovial fluid $(S F)$ in patients with osteoarthrosis and rheumatoid arthritis

\begin{tabular}{|c|c|c|c|c|c|c|c|c|}
\hline & $\begin{array}{l}\text { Total protein } \\
(\mathrm{g} / \mathrm{l})\end{array}$ & $S F / S$ & $\begin{array}{l}\text { Albumin } \\
(\mathrm{g} / \mathrm{l})\end{array}$ & $S F / S$ & $\begin{array}{l}\text { Transferrin } \\
(g / l)\end{array}$ & $S F / S$ & $\begin{array}{l}\text { Caeruloplasmin } \\
(\mathrm{mg} / \mathrm{l})\end{array}$ & $S F / S$ \\
\hline \multicolumn{9}{|l|}{ Osteoarthrosis $(n=40)$} \\
\hline Synovial fluid & $32 \cdot 0 \pm 7 \cdot 0$ & 0.46 & $25 \cdot 4 \pm 6 \cdot 9\}$ & 0.64 & $1 \cdot 58 \pm 0 \cdot 55\}$ & 0.63 & $141 \pm 62 J$ & 0.42 \\
\hline \multicolumn{9}{|l|}{$\begin{array}{l}\text { Rheumatoid } \\
\quad \text { arthritis }(n=40)\end{array}$} \\
\hline Serum & $69 \cdot 0 \pm 4 \cdot 8\}$ & \multirow{2}{*}{$0 \cdot 55$} & $43 \cdot 4 \pm 3 \cdot 7$ & \multirow{2}{*}{0.61} & $2 \cdot 29 \pm 0.67$ & 0.72 & $451 \pm 87$ & \multirow{2}{*}{0.69} \\
\hline Synovial fluid & $38 \cdot 0 \pm 9 \cdot 0$ & & $26 \cdot 6 \pm 4 \cdot 8\}$ & & $1 \cdot 66 \pm 0.65\}$ & & $310 \pm 165\}$ & \\
\hline
\end{tabular}

and caeruloplasmin in both the RA group $(r=$ $0.596 ; P<0.001)$ and the osteoarthrotic group $(r=0.362 ; P<0.01)$. The results are summarised in Table 1.

The mean non-caeruloplasmin-bound copper in the osteoarthrotic group was calculated as $3 \cdot 53 \pm 0 \cdot 1$ $\mu \mathrm{mol} / 1(22.48 \pm 0.6 \mu \mathrm{g} / 100 \mathrm{ml})$. In the rheumatoid group there was a calculated copper 'deficit' in terms of the caeruloplasmin detected immunologically. In other words, in rheumatoid synovial fluids copper was insufficient to account for all the caeruloplasmin measured.

TOTAL PROTEIN ALBUMIN AND TRANSFERRIN The mean total protein content of rheumatoid synovial fluid was significantly higher $(\mathrm{P}<0.02)$ than that of osteoarthrotic fluid. Mean levels of synovial fluid albumin and transferrin were not significantly different. The partition ratio for caeruloplasmin in the osteoarthrotic group was 0.42 while in the RA group it was 0.69 . These results are summarised in Table 2.

\section{Discussion}

The permeability of synovial membrane to plasma proteins is poorly understood. It is a highly selective process which probably depends on molecular size, molecular weight, and metabolic changes in the joint as well as on the plasma concentration of different proteins. Damage to or destruction of the membrane will result in loss of its ability to selectively limit or exclude certain plasma proteins. The changes induced by acute or subacute inflammation may be superimposed on this pattern. Our results show that a raised synovial fluid caeruloplasmin is characteristic of rheumatoid, as distinct from osteoarthrotic, effusions. This difference, moreover, is considerably greater than the difference between total protein concentrations; and caeruloplasmin concentration in relation to total protein concentration is higher in rheumatoid synovial fluid than in rheumatoid serum. Whether similar changes occur in other inflammatory effusions remains to $\mathrm{Ee}$ established. The rise in synovial fluid caeruloplasminat (as in serum caeruloplasmin) may be related to the protein's powerful antioxidant action (Al-Timimi and Dormandy, 1977). This may be part of the acuse inflammatory response of the body and may have a protective significance.

The relation between copper and caeruloplasm $\$$ in synovial fluid differs from that in serum and differs in osteoarthrotic and rheumatoid effusions. In osteoarthrotic fluid the copper/caeruloplasmin ratio is marginally reduced compared to serum the relation still suggests that virtually all the coeper is caeruloplasmin-bound. In rheumatoid fluid teese is a copper 'deficit', i.e. insufficient copper account for all the caeruloplasmin as measured by immunodiffusion. It is possible that some of the synovial fluid caeruloplasmin is chemically but nat immunologically partially degraded and holds les than the $8 \mathrm{~g}$ atoms copper per molecule characteistic of the serum protein fraction.

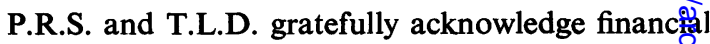
support by the Arthritis and Rheumatism Counsil for Research and the North East Thames Region Hospital Authority.

\section{References}

Al-Timimi, D. J., and Dormandy, T. L. (1977). The inhibition of lipid autoxidation by human caeruloplasmin. $B \overline{\bar{g}}$ chemical Journal, 168, 283-288.

Kasper, C. B., and Deutsch, H. F. (1963). Physicochemigal studies of human caeruloplasmin. Journal of Biologiß Chemistry, 238, 2325-2338.

Mancini, G., Carbonara, A. O., and Heremans, J. F. (19 Immunochemical quantitation of antigens by single radial immunodiffusion. Immunochemistry, 2, 235-242.

Scudder, P. R., Al-Timimi, D., McMurray, W., White, A. Zoob, B. C., and Dormandy, T. L. (1978). Serum copper and related variables in rheumatoid arthritis. Annals of the Rheumatic Diseases, 37, 67-70. 